量のオキシンの滴定に応用された 短絡し, 覀鉛棒の滴定液中に浸る部分の長さを機械的に 変えることによって電流を調節するという簡単な装置が 作られ, 還元滴定に用いられた ${ }^{54)}$. 慣性の小さな積分モ一 ターを用いて電量を測定する方式が報告されたが55)，こ の方法によれば電流を精密に一定とする必要も, 測時の 必要もない点便利であろう・トランジスタ一回路が 100 $\mu \mathrm{A} \sim 5 m \mathrm{~A}$ の定電流電源として用いられることが報告 され，また出力を連続的に変化させることもできるので, 電流走査のポーラログラフの電源としても用いられるこ とが示された ${ }^{56)}$. 数 $100 m \mathrm{~A}$ の定電流が $0.1 \%$ の精度で 得られる装置が作られた ${ }^{57}$ )。連続電量分析装置が作ら れ ${ }^{58)}$ ，これを安定に操作するための条件について検討さ れた59)。また終点検知に双金属電流滴定法を利用する方 式の自動滴定装置も作られた ${ }^{60)}$. 自動記録装置も作られ た

\section{文 献}

1) 高橋炤：化学の領域， 9, 49 ('55)：2） D. D. DeFord: Anal. Chem., 28, 662 ('56)； 3) 桃木弘三:分化, 4, 646 ('55); 4) 藤永太一郎, 武藤義一:分化, 4, 321 ('55)； 5) 武藤義一: 電化, 24, 605 ('56); 6) E. H. Swift: Anal. Chem., 28, 1804 ('56); 7) T. Meites, L. Meites: ibid., 27, 1531 ('55); 8) J. J. Lingane, J. A. Page: Anal. Chim. Acta, 13, 281 ('55); 9) W. M. MacNevin, R. D. McIver: Anal. Chem., 27, 1994 ('55); 10) L. Meites: ibid., 27, 1114 ('55)

11) L. Meites, T. Meites: Anal. Chem., 28, 103 ('56); 12) L. Meites: ibid., 27, 1116 ('55); 13) T. C. Franklin, C. C. Roth: ibid., 27, 1197 ('55); 14) H. W. Hoyer: J. Phys. Chem., 60, $\left.372\left({ }^{\prime} 56\right) ； 15\right)$ 桝井雅一郎, 佐用博照: 薬学 誌, 75, 1515 ('55); 16) M. Masui, H. Sayo, Y. Nomura: Pharm. Bull. (Tokyo), 4, 337 ('56); 17) H. Gerischer, W. Vielstich: Z. phys. Chem. (Neue Folge), 3, 16 ('55); 18) J.S. Parsons, W. Seaman: Anal. Chem., 27, 210 ('55); 19) J. J. Lingane, R. T. Iwamoto: Anal. Chim. Acta, 13, 465 ('55); 20) H. V. Malmstadt, C. B. Roberts: Anal. Chem., 27, 741 ('55)

21) J. J. Lingane, J. H. Kennedy: Anal. Chim. Acta,
15, 465 ('56); 22) W. D. Shults, P. F. Thomason, M. T. Kelley: Anal. Chem., 27, 1750 ('55); 23) K.W. Edwards, D. M. Kern: ibid., 28, 1876 ('56); 24) R. W. Schmid, C. N. Reilley: ibid., 28, 520 ('56): 25) H. H. Stein: Anal. Abstr., 4, 2483 ('57); 26) J. M. Dunham, P. S. Farrington: Anal. Chem., 28, 1510 ('56): 27) G. M. Arcand, E. H. Swift: ibid., 28, $440\left({ }^{\prime} 56\right) ;$ 28) P. S. Tutundzic, S. Mladenovic: Anal. Chim. Acta, 12, 382 ('55); 29) P.S. Tutundzic, S. Mladenovic: ibid., 12, $\left.390\left({ }^{\prime} 55\right) ; \quad 30\right)$ D. Monnier, P. Zwahlen: Helv. Chim. Acta, 39, 1865 ('56)

31) R. V. Dilts, N. H. Furman: Anal. Chem., 27, 1275 ('55); 32) R. V. Dilts, N. H. Furman, ibid., 27, 1596 ('55); 33) N. H. Furman, A. J. Fenton, ibid., 28, 515 ('56); 34) T. Takahashi, K. Kimoto, H. Sakurai: Rept. Inst. Ind. Sci., Univ. Tokyo, 5, 133 ('55); 35) A. M. Hartley, J. J. Lingane: Anal. Chim. Acta, 13, 183 ('55); 36) K. Rowley, E. H. Swift: Anal. Chem., 27, 818 ('55); 37) W.C. Purdy, E. A. Burns, L. B. Rogers: ibid., 27, 1988 ('55); 38 ) J. J. Lingane, F. C. Anson: ibid., 28, 1871 ('56); 39) C. N. Reilley, W. W. Porterfield: ibid., 28, 443 ('56); 40) D. D. DeFord, H. Horn: ibid., 28, 797 ('56)

41) E. P. Przybylowicz, L. B. Rogers: Anal. Chem., 28, 799 ('56); 42) P.S. Tutundzic, I. Doroslovacki, O. Tatic: Anal. Chim. Acta, 12, 481 ('55); 43) M. Nakanishi: Natural Sci. Rept. Ochanomizu Univ., 6, 103 ('55); 44) C. A. Streuli: Anal. Chem., 28, 130 ('56); 45) R. B. Hanselman, C. A. Streuli: ibid., 28, 916 ('56); 46) F. A. Leisey, J. F. Grutsch: ibid., 28, 1553 ('56); 47) W. N. Carson, H. S. Gile: ibid., 27, 122 ('55); 48) R. Schreiber, W. D. Cooke: ibid., 27, 1475 ('55); 49) D. W. Einsel, H. J. Trurnit, S. D. Silver, E. C. Steiner: ibid., 28, 408 ('56); 50) P. S. Farington, D. T. Sawyer: J. Am. Chem. Soc., 78, $5536(' 56)$

51）高橋武雄：分化, 6, 590('57)； 52) M. A.V. Devanathan, Q. Fernando: J. Sci. Instr., 33, 323 ('56); 53) M. A. V. Devanathan, Q. Fernando: Trans. Faraday Soc., 52, 1332 ('56); 54) J. S. Hetman: Analyst, 81, 543 ('56); 55) J. S. Parson, W. Seaman, R. M. Amick: Anal. Chem., 27, 1754 ('55); 56) N. H. Furman, L. J. Sayegh, R. N. Adams: ibid., 27, 1423 ('55); 57) G. E. Gerhardt, H. C. Lawrence. J. S. Parsons: ibid., 27, 1752 ('55); 58) 高橋昭, 山本啓太, 山下渠, 計测, 5, 190('55)； 59）山本塸太, 高橋昭, 山下熙: 計测, $\mathbf{5}$, 347 ('55): 60) H. L.Richter: Anal, Chem., 27, 1526 ('55); 61）山下政夫, 花村茂樹:名工技試報, 4, 264 ('55)； 62) 山下 政夫, 花村茂樹: ibid., 4, $\left.270\left({ }^{\prime} 55\right) ; 63\right)$ 山下政夫, 花村茂樹: ibid., 5, 231 ('56)

\title{
14 炎光光度分析
}

\section{音 在 清 輝・福 島 昭 三*}

\section{$14 \cdot 1$ 解 説, 綜 説}

炎光分析においても本格的な教科書62)112)が現われた。 また一般的な解説(3)12)34;48)50)122)123)130) や綜説87)89)113)115)。

* Kiyoteru Otozai, Shouzow Fukushima: Faculty of Science, Osaka University, Osaka, Japan. (大阪大学理学 部化学教室)
128,129)132）が盛であり特に臨床医学的な分野の綜説 ${ }^{15) 171)}$ も行われた。

\section{$14 \cdot 2$ 対 象 元 素}

依然アルカリ，アルカリ土類元素を対象とするもの が压倒的に多いがその他の元素を対象とする研究も多 
くなつた. $\mathrm{Ag}^{145)}, \mathrm{Al}^{180)}, \mathrm{B}^{26)}, \mathrm{Co}^{18) 153) 180)}, \mathrm{Cr}^{18) 80) 180)}$, $\mathrm{Cu}^{28) 30)(03)(53) 180)}, \mathrm{Fe}^{25) 2() 29)(06) 153) 180)}, \mathrm{Ga}^{116)}, \mathrm{La}^{25)(3)}$,

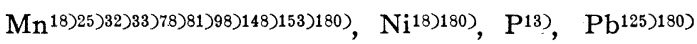
などが直接法で定量され， $\left.\mathrm{Cl}^{64)}, \mathrm{F}^{85}\right)$ が夫々 $\mathrm{CuCl}, \mathrm{CaF}$ の発光により定量された. また Ca に及ぼす干涉を逆用

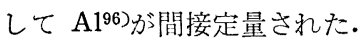

\section{$14 \cdot 3$ 炎の中の反応と共存物の干渉}

炎光分析研究の中心課題は “共存物の干渉”であるが その干渉現象の場たる炎自身の解明において種々の業蹟 がある. 全般的な解説書として有名な B. Lewis, G. von Elbe の書物程実験データはないがストーリイの明 快な書物が出た ${ }^{51)}$.

炎の温度測定については数年前程多くの文献はないが

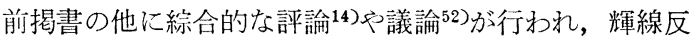

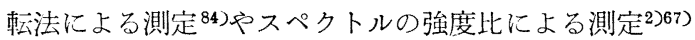
97135)182)が試みられた。

発光や共存物の干渉を本質的に論議するには色々な化 学種の個々の濃度を知ることが大切であるが，この困難 な問題にも手がつけられるようになつた。 マイクロ波吸 収による電子密度の測定がさらに発展し ${ }^{156)}$, これと金属 の発光強度の解析とからアルカリ元素の挙動が解明さ れ167)， $\mathrm{Na}$ におては $\mathrm{Na}^{+}, \mathrm{NaH}, \mathrm{NaOH}$ など殆え どなく, 他のアルカリ, アルカリ土類元素では複雑な化 学種が形成されることがわかつた。これを利用して $\mathrm{H}$, $\mathrm{OH}, \mathrm{O}, \mathrm{OH}^{-}$の濃度が測定され, アルカリ土類元素の 場合には $[\mathrm{MOH}]^{+},[\mathrm{OM} \cdot \mathrm{OH}]-$ のよな奇妙なイオ ンの存在が推定され，またこれらの化学種の熱平衡から のずれが定量的に諭ぜられるようになつた 168)170).

また $\mathrm{D}$ 線の発光, 吸収, 自己吸収を組合せて, 基底状 態むよび励起状態の $\mathrm{Na} の$ 絶対濃度が測定された ${ }^{93}$.

またこのような論議のために従来欠けていた関連化学 種の平衡計算に必要な熱力学データが整備された ${ }^{16) 53)}$ 92)93)169)170)181).

遊離基の発光, 吸収により直接その濃度を測定した り 67)135)187)，今まで明確でなかったアルカリ土類元素の

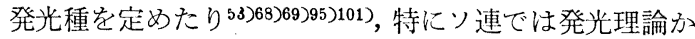

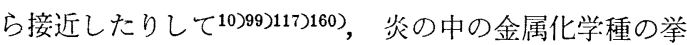
動が次第に解明されて来て, 例えば各元素の励起には個 有の最適温度があるという知見 ${ }^{86)}$ ，アルカリ相互の相乗 干渉は低温程少いという知見142)144)などの内容が想像出 来るようになった。

干渉の機作に関しては従来噴霧速度，噴霧粒度，炎の 温度などの変化, 炎中の発光金属の関与する電離平衡, 解
離平衡の移動，難発光性化合物の生成などの諸説が行わ れて来たが，その綜合的な解説や研究8;45)55)134)138)1411175) が見られ，特にアルカリ相互の電離平衡に対する考察か ら, $\mathrm{N}_{2}$ で稀勫し適当に炎の温度を下げれば相互の干渉が なくなるという研究144) の進め方は一つの典型を与える ものと思われる. 有名なアルカリ土類に対する $\mathrm{PO}_{4}{ }^{3-}$, $\mathrm{A} 1, \mathrm{Cr}, \mathrm{SO}_{4}{ }^{2-}$ などの消光作用に関しては発光金属と 干涉物との当量関係に注目し難発光性化合物生成説が検 討された76)105)(151)176).

\section{$14 \cdot 4$ 装置の改良, 試作}

シアン-酸素の炎は $5000^{\circ} \mathrm{K}$ 近い温度を与えることが 知られているが2122)，乙れを炎光分析の光源としてとり 入れ, $\mathrm{A} 1$ を直接発光し, その他 $\mathrm{Ba}, \mathrm{Ca}, \mathrm{Co}, \mathrm{Cr}$, $\mathrm{Cu}, \mathrm{Fe}, \mathrm{Mg}, \mathrm{Mn}, \mathrm{Ni}, \mathrm{Pb}, \mathrm{Sr}$ の定量限界を下げる ことが試みられた ${ }^{180)}$.

静電力気を駆電力とした珍らしい新噴霧方式のバーナ 一が発明され ${ }^{165)}$, 引火性溶媒を安全に取扱える噴霧器が 考案44)された他簡易な圧力調整器6), 種々の噴霧バーナ 一の自作が報告された

特定の光をとり出すのに分光器や滤光板を使わない “optical-electrical-filter”なるものが現われた4が， これは光を二光路に分け，一方に目的元素により着色し た炎を置き，目的元素からの光の夕吸収させ両光路の光 を chopper で交互に光電管に入れて吸収分のみ交流信 号にし増巾する方式である.

$\mathrm{Na}, \mathrm{K}, \mathrm{Mg}, \mathrm{Ca}, \mathrm{Sr}$ の五元素を同時定量しようと いう五光路方式の炎光分光光度計が試作され ${ }^{179)}$, さらに これを利用してバックグラウンドを自動的に差引くこと が試夕られ ${ }^{104)}$, 単光路方式を内部標準測定に便利にする 工夫がなされた

Beckman DUを自記式に改造する色々な工夫 ${ }^{121161) . ~}$ 183)，や指針の変動を少くするための電気回路の改良 ${ }^{147)}$ がなされ，放射性試料を安全に取扱うためにダクトと滤 過器がとりつけられた ${ }^{39}$.

\section{$14 \cdot 5$ 特殊な試料調整法}

ガソリン試料を直接噴霧することが実用され125；，ク ロロホルム18)30), アミール・アルコール44), アミール・ アセテート 30), アセチル・アセトン29)153), メタノー ル26)73)103)1073192)が抽出分離および増感の目的に利用され た．増感戍となる有機物の調査が行われた ${ }^{158) 166)}$ 他，以 前からよく使われたイソプロピル・アルコール41)(1)102), アセトン145)などもよく利用されている。 


\section{$14 \cdot 6$ 干渉を除去するための化学操作}

固体試料の場合一且完全に溶解するよりも目的によっ ては目的元素の選択溶解をした方が便利なことがある。 例えば肥料中の水溶性 $\mathrm{K}$ は水で抽出し 全Kは $\mathrm{HCl}$ で 抽出単離され ${ }^{155)}$, 薬剂中の $\mathrm{Co}, \mathrm{Cu}, \mathrm{Fe}, \mathrm{Mg}, \mathrm{Mn}$ が $\mathrm{HCl}$ で抽出された ${ }^{153)}$.

水溶液試料から目的元素を抽出単離する例としては

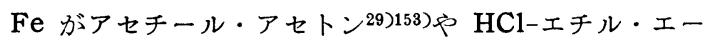
テル25)で抽出され，大量の $\mathrm{Fe}$ から $\mathrm{Cu}$ を単離するのに $\mathrm{Fe}$ の混入を防ぐためくえん酸アンモンを加えて $1 \%$ サ リチル・アルドキシムのクロロホルム溶液または醋酸ア ミル溶液で抽出され30)，鉄合金中の $\mathrm{Co}, \mathrm{Cr}, \mathrm{Mn}, \mathrm{Ni} の$ 定量に際し Ni-ヂメチル・グリオキシムがクロロホルム で抽出された18).

水溶液試料から干涉元素を抽出除去する例としては同

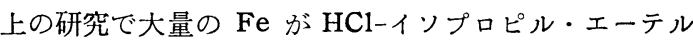
で抽出除去され ${ }^{18)}$ ， Ca の定量に際し Al を除去するた めに Al-オキシンがベンゼンで抽出され192), U中のFe, La, Mg の定量に際しウラニールがエチル・エーテルで 抽出除去された25).

水溶液試料から目的元素を沈澱単離する例としては常 法により微量の $\mathrm{Ca}$ を苳酸塩として落したり， $\mathrm{Mg}$ を $\mathrm{MgNH}_{4} \mathrm{PO}_{4}$ や $\mathrm{Mg}$-オキシンとして落したり，K， $\mathrm{Na}$ を $\mathrm{KClO}_{4}+\mathrm{KCl}+\mathrm{NaCl}$ として落したり ${ }^{126)}$ するのが多 いが，干渉元素を沈澱除去する例としてはU 中の微量 Ca を定量するのに EDTA を使って Ca を保護しなが らUを $\mathrm{NH}_{3}$ で沈澱除去したり ${ }^{164)}$, 大量 $\mathrm{K}$ 共存下の $\mathrm{Na}$ の定量に際しテトラフェニール硼酸で $\mathrm{K}$ を沈澱除

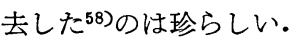

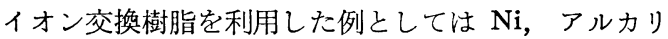
共存下の $\mathrm{Ca}$ の定量に際し $\mathrm{Ni}$ をシアン錯陰イオンとし て陽イオン交換樹脂を通過させてアルカリと Ca を捕捉 し $0.5 \mathrm{n}-\mathrm{HCl}$ でアルカリを洗い出し $4 \mathrm{n}-\mathrm{HCl}$ で $\mathrm{Ca}$ 抽出単離したり ${ }^{192)}, \mathrm{Na}$ 共存下の $\mathrm{Li}$ の分析でイオン交

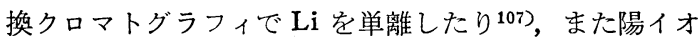
ン交換樹脂(1)109)149)や陰イオン交換樹脂54)90)108)136)137) で 試料溶液中の陰イオンを整頓し干渉陰イオンを除去した のがある。

また $\mathrm{Ni}$ 中の $\mathrm{Ca}$ の分析で水銀陰極電解法で $\mathrm{Ni}$ か 電解除去された ${ }^{192)}$.

以上の分離操作は分析化学の常法を炎光分析に応用し たものであるが炎光分析特有の化学操作として次のよう なものもある・

干渉物の濃度が变動しても干渉の度合が变化しないよ
うな領域を現出するような第三体を分光学的緩衝剤とい い，これを利用した例として， $\mathrm{Na} ＼textrm{K}$ の相互干涉に対 し多量の $\mathrm{BaCl}_{2}{ }^{59}$ )， $\mathrm{Ca}, \mathrm{Mg}$ の相互干涉に対し多量の $\mathrm{NH}_{4} \mathrm{Cl}^{154)}, \mathrm{Ca}$ に対する $\mathrm{PO}_{4}{ }^{3-}$ などの干涉に対し $\mathrm{H}_{2} \mathrm{SO}_{4}{ }^{173)}, \mathrm{Sr}+\left(\mathrm{NH}_{4}\right)_{2} \mathrm{HPO}_{4}{ }^{9)}$ が有効と報告された。

分光学的緩衝剤の特別の場合として干涉のなくなるも のを干涉防止剂というが，これを利用した例としてアル カリに対する大量のアルカリ土類の相加干涉が A1 の添 加により防止された ${ }^{151) 162) . ~}$

\section{$14 \cdot 7$ 標準との比較による濃度推定操作}

干渉があるままで正しい濃度を推定する操作としては 大抵は試料溶液と標準溶液とで干涉の度合が等しくなる ようにする等干涉法が使われるが，特殊な方法も二三試 みられた。

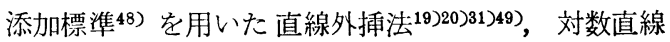

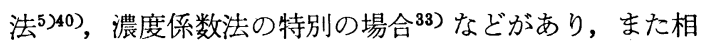
加干涉の加成性を利用して図または計算で補正する連立 方程式法が $\mathrm{K}, \mathrm{Ga}$ 共存下の $\mathrm{Mn}$ の定量 ${ }^{98)}, \mathrm{Ca}, \mathrm{Mg}$ の同時定量 ${ }^{75) 191)}, \mathrm{Ca}$ 共存下の $\mathrm{Li}, \mathrm{Na}, \mathrm{K}$ の定量 ${ }^{143)}$ などで実用された。

\section{$14 \cdot 8$ 炎光分析の実用例}

実用分析においては実用例を参考にすることが大切で あるから以下 1955 年, 1956 年（但し国内文献は 1953 年〜1956 年）から比較的原文入手が容易であると見ら りるものを対象とした文献集を附すことにする.

\subsection{1 海水の分析 $\mathrm{Ca}^{20)} ; \mathrm{Cl}^{64)}$; $\mathrm{Sr}^{19)}$}

14.8.2 水の分析 $\mathrm{Ca}^{186)}$; $\mathrm{Ca}, \mathrm{Fe}, \mathrm{Mg}, \mathrm{Na}^{106)}$; $\mathrm{Ca}, \mathrm{K}, \mathrm{Li}, \mathrm{Na}^{193)}$; $\mathrm{Ca}, \mathrm{K}, \mathrm{Na}, \mathrm{Sr}^{166)} ; \mathrm{K}^{108)} ; \mathrm{K}$, $\mathrm{Na}^{109) 118)} ; \mathrm{Li}^{107)}$; $\mathrm{Na}^{90)}$

$14 \cdot 8 \cdot 3$ 飲料の分析 ウイスキー中の $\mathrm{Cs}, \mathrm{Rb}^{140}$; ウイスキー中の $\left.\mathrm{Li}, \mathrm{Sr}^{139}\right)$

14.8 .4 食品の分析 $\mathrm{Ca}, \mathrm{K}, \mathrm{Mg}, \mathrm{Na}^{136)} ; \mathrm{K}, \mathrm{Na}^{70}$ ) 14.8.5 植物性試料の分析 $\mathrm{Ca}^{61) 137) 173)} \mathrm{Ca}, \mathrm{K}$, $\mathrm{Na}^{162)} ; \mathrm{K}^{110)}, \mathrm{K}, \mathrm{N},{ }^{111) 124)} ; \mathrm{Mn}^{81) 98)} \mathrm{Na}^{60}$ )

14.8 .6 生体試料の分析 $\mathrm{Ca}^{974171)} \mathrm{Ca}, \mathrm{K}, \mathrm{Mg}$, $\mathrm{Na}^{171) 178)}$; $\mathrm{Ca}, \mathrm{K}, \mathrm{Na}^{73(5) 63)}$; $\mathrm{Ca}, \mathrm{Mg}^{38)} ; \mathrm{K}^{157)} ; \mathrm{K}$,

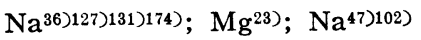

14.8.7 土の分析 $\mathrm{Ba}^{150)} ; \mathrm{Ca}^{100)} ; \mathrm{Ca}, \mathrm{K}, \mathrm{Mg}$,

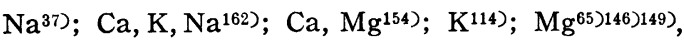
$\mathrm{Na}^{35)}$

\section{$14 \cdot 8 \cdot 8$ 肥料の分析 $\mathrm{K}^{46) 54)(55)}$}

14.8 .9 セメントの分析 $\quad \mathrm{K}, \mathrm{Na}^{43)} ; \mathrm{Mn}^{32)} ; \mathrm{Sr}^{31)}$
$14 \cdot 8 \cdot 10$ ガラスの分析 $\quad \mathrm{Ba}, \mathrm{Ca}, \mathrm{K}, \mathrm{Li}, \mathrm{Na}^{189)}$;


$\mathrm{Ba}, \mathrm{Ca}, \mathrm{Mg}^{185)}$; $\mathrm{Ca}, \mathrm{K}, \mathrm{Mg}, \mathrm{Mn}, \mathrm{Na}^{148)}$; $\mathrm{Ca}, \mathrm{K}$, $\mathrm{Na}{ }^{11)} ; \mathrm{Fe}^{27)} ; \mathrm{K}, \mathrm{Na}^{57) 58) 59)(88)}$; $\mathrm{Na}^{177)}$

$14 \cdot 8 \cdot 11$ 鉱物, 珪酸塩の分析 $\mathrm{Ca}, \mathrm{K}, \mathrm{Na}^{82} ; \mathrm{Ca}$, $\mathrm{Mg}^{191)}$; $\mathrm{Cs}, \mathrm{Li}, \mathrm{Rb}^{66)}$; $\mathrm{K}^{56)}$ K, Li, $\mathrm{Na}^{143)}$; $\mathrm{Na}^{88)}$; $\mathrm{Li}^{42) 91) 172)}{ }^{4{ }^{33}} \mathrm{Mn}^{31)}$; $\mathrm{Sr}^{79}$ )

14.8.12 非鉄金属の分析 $\mathrm{Al}^{96) 119) ;} \mathrm{Ba}, \mathrm{Ca}, \mathrm{Sr}^{11}$; $\mathrm{Ca}^{164) 192)}$; $\mathrm{Cs}^{184)} ; \mathrm{Cu}^{28)} ; \mathrm{Fe}^{29)} ; \mathrm{Fe}, \mathrm{Mg}, \mathrm{La}^{25)} ; \mathrm{Ga}^{116)}$; $\mathrm{Mg}^{71)} ; \mathrm{Na}^{49) 72)}$

\section{$14 \cdot 8 \cdot 13$ 鉄合金の分析 $\mathrm{Co}, \mathrm{Cr}, \mathrm{Mn}, \mathrm{Ni}^{18)} ; \mathrm{Cr}^{80}$; $\left.\mathrm{Cu}^{30)} ; \mathrm{Mn}^{33}\right)(8)$}

14.8.14 試薬, 薬品の分析 $\mathrm{Ca}, \mathrm{Na}^{152) 190)}$; $\mathrm{Co}$, $\left.\mathrm{Cu}, \mathrm{Fe}, \mathrm{Mg}, \mathrm{Mn}^{153}\right)$

14.8.15 化学工業関係の分析 スラッグ中の $\mathrm{Ca}^{163)}$;

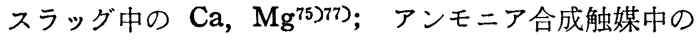
$\mathrm{K}^{126)}$; 触媒中の $\mathrm{Ca}, \mathrm{K}, \mathrm{Li}, \mathrm{Na}^{193)}$

\subsubsection{6 その他の無機物の分析 燐光体中の $\mathrm{Ag}^{145)}$;}

燐光体中の $\mathrm{K}, \mathrm{Na}^{24}$ )

$14 \cdot 8 \cdot 17$ 石油関係の分析 ガソリン中の $\left.\mathrm{Pb}^{125}\right)$
$14 \cdot 8 \cdot 18$ その他の有譏物の分析 有機物中の $\mathrm{P}^{13)}$

\section{文 献}

1) Gy. Gergely. F. P. Váradi: Magyar Kem. Foly., 61, 182 ('55); Z. anal. Chem., 157, 131 ('57): J. Ádam. K. Etre, G. Gergely, F. P. Váradi: Magyar Kem. Foly., 62, 223 ('56); Anal. Abst., 4, 754 ('57); 2) I. Agîrbiceanu, M. Hagiescu: Comun. acad. rep. populare Romîne, 5, 1263 ('55); C. A., 50, 16377c; 3) C. T. J. Alkemade: "Contribution to the Development and Understanding of Flame Photometry" ('54), (Univ. of Utrecht, Holland); 4) C. T. J. Alkemade, J. M. W. Milatz: Appl. Sci. Research, 4B, 288 ('55); C. A., 49, 12966 h; 5) C. H. Anderson, C. D. Beatty: Anal. Chem., 26, 1369 ('54)； 6) 浅野千秋: 分 化, 5, 347 ('56); 7) R. W. R. Baker: Biochem. J., 59, 566 ('55); 8) A. D. Berneking: Univ Microfilms, No. 13591 ('55),(Ann Arbor, Mich.); 9) D. Bernhardt, R. Herrman: Ärtzl. Wochschr., 10, 61 ('55); C. A., 49, 8364f; 10) L. M. Biberman, E. M. Novodvorskaya Soviet Phys. Doklady, 1, 5 ('56): C. A., 51, 6330 h; ibid., 50, 14341 e.

11) D. Billings: Glass Ind., 36, 255, 280 ('55); C. A., 49, $15196 \mathrm{f}$; 12) E. C. Boycks: Univ. Micro Films, No. 14759, ('55), (Ann Arbor, Mich.); 13) D. W. Brite: Anal. Chem., 27, 1815 ('55); 14) H. P. Broida: " Experimental Temperature Measurements in Flames and Hot Gases," 2, 265 ('55), (Reinhold, New York); 15) D. E. Brown: Tech. Bull. Registry Med. Technologists, 26, 133 ('56); Am. J. Clin. Pathol., 26, 807 ('56); 16) E. M. Bulewicz, T. M. Sugden: Trans. Faraday Soc., 52, 1475 ('56); 17) E. M. Bulewicz, C. G. James, T. M. Sugden: Proc. Roy. Soc. (London), 235A, 89 ('56); 18) F. Burriel, I. Ramírez-Muñoz, M. del Carmen Asunción-Omaren menteria: Mikrochim. Acta, 1956, 362; 19) T. J. Chow, T. G. Thompson: Anal. Chem., 27, 18 ('55); 20) T. J. Chow, T. G. Thompson: ibid., 27, 910 ('55)

21) J. B. Conway, R. H. Wilson, Jr., A. V. Grosse: J. Am. Chem. Soc., 75, 499 ('53); 22) J. B. Conway, W. F. R. Smith, W. J. Liddell, A. V. Grosse: J. Am. Chem. Soc., 77, 2026 ('55); 23) S. Davis: J. Biol. Chem., 216, 643 ('55); 24) S. B. Deal: Anal. Chem., 26, 598 ('54);
25) J. F. P. de Albinati: Anales asoc. quím. argentina, 43, 106 ('55); C. A., 50, 4706 g; 26) J. A. Dean, C. Thompson: Anal. Chem., 27, 42 ('55); 27) J. A. Dean, J. C. Burger, Jr.: ibid., 1052 ('55): 28) J. A. Dean: ibid., 1224 ('55); 29) J. A. Dean, J. H. Lady: ibid., 1533 ('55); 30) J. A. Dean, J. H. Lady: ibid., 28, 1887 ('56)

31) J. J. Diamond: Anal. Chem., 27, 913 ('55); 32) J. J. Diamond: ibid., 28, 328 ('56); 33) W. A. Dippel, C. E. Bricker: ibid., 27, 1484 ('55); 34) W. A. Dippel: Univ. Microfilms, No. 13685, ('56), (Ann Arbor. Mich.); 35) R. Domansky: Chem. Zvesti., 10, 32 ('56): C. A., 50, 8383i: 36) R. L. Dryer: Clin. Chem., 2, 112 ('56); C. A., 50, 13160d; 37) K. P. Dubrovin: Univ. Microfilms, No. 18393, ('56), (Ann Arbor, Mich.); 38) H. J. Dulce: HoppeSeylers' Z. Physiol. Chem., 302, 102 ('55); 39) J. H. Edgerton, H. G. Davis, L. C. Henley, M. T. Kelley: Anal. Chem., 28, 557 ('56); 40) H. J. Eichhoff, E. Mainka: Mikrochim. Acta., 1955, 298

41) B. T. Elert: Am. J. Med. Technol., 21, 297 ('55); C. A., 50, 7931g; 42) R. B. Ellestad, E. L. Horstman: Anal. Chem., 27, 1229 ('55); 43) O. A. Ellingson, J. L. Gillam, J. E. Kopanda: A. S. T. M. Bull. No. 212, 63 ('56); 44) A. Fink: Mikrochim. Acta, 1955, 314; 45) J. Fischer, A. Doiwa: ibid., 1956, 353; 46) O. W. Ford: J. Assoc. Offic. Agr. Chem., 38, 445 ('55)；47) 藤井徹: 阪市 大医誌，5, 57 ('56)；48) 福島略三: “炎光分光光度法” (分析化 学諢座, 機器分析編, 6, ('56) (共立出版, 東京)；49）福島昭三, 岩田志郎, 久米三四郎, 繁本美砂子: 分化, 5, $\left.704\left({ }^{\prime} 56\right) ; 50\right)$ K. W. Gardiner: "Physical Method in Chemical Analysis" 3, 219 ('56), (Acdemic Press, New York)

51) A. G. Gaydon, H. G. Wolfhard: "Flames, their Structure, Radiation and Temperature" ('53), (Chapman and Hall, London); 52) A. G. Gaydon: Natl. Bur. Standards, Circ., 523, 1('54); 53) A. G. Gaydon: Proc. Roy. Soc. (London), A231, 437 ('55); 54) C. W. Gehrke, H. E. Affsprung, E. L. Wood: J. Agr. Food Chem., 3, 48 ('55); 55) 後藤秀弘：化学々工業, 9, 350 ('56); 56) I. G. Gurvich, E. I. Khanaev: Izuvest. Akad. Nauk S. S. S. R., Ser. Geol., 1956, No. 6, 101; C. A., 51, 6433e: 57) F. Hegemann, B. Pfab: Glastech. Ber., 28, 85('55); Z. anal. Chem., 153, 135; 58) F. Hegemann, B. Pfab: Glastech. Ber., 28, 242 ('55); Z. anal. Chem., 153, 136; 59) F. Hegemann, B. Pfab: Glastech. Ber., 28, 437('55); Z. anal. Chem., 153, 136; 60) E. J. Heinen: J. Assoc. Offic. Agr. Chem., 38, 391 ('55)

61) R. G. Hemingway: Analyst, 81, 164 ('56); 62) R. Herrmann: "Flammen Photometrie" ('56), (Springer, Berlin); 63) A. Hilgers: Hoppe-Seyler's Z. Phoysiol. Chem., 304, 193 ('56); 64) M. Homma: Anal. Chem., 27, 1656 ('55); 65) G. C. Horn: Univ. Microfilms, No. 19173 ('56), (Ann Arbor, Mich.); 66) E. L. Horstman: Anal. Chem., 28, 1417 ('56); 67) L. Huldt, E. Knall: Naturwiss., 41, 421('54); 68) L. Huldt, E. Knall: Arkiv. Fysik, 11, 229 ('56); C. A., 51, 1729d; 69) L. Huldt, A. Lagerqvist: Arkiv. Fysłk, 11, 347 ('56); C. A., 51, 7850g; 70) Wm. H. Hulet: Am. J. Med. Sci., 229, 81 ('55)

71) F. L. Humoller, J. R. Walsh, M. F. Wharton: J. Lab. Clin. Med., 48, 127 ('56); Z. anal. Chem., 155, 395; 72）池田重良：日化， 76，354 ('55)：Sci. Repts. Research Insts. Tohoku Univ. Ser. A, 7, 29 ('55)；73）池田重良：日 化, 76, 783 ('55); Sci. Repts. Research Inst. Tohoku Univ. Ser. A, 7, 575 ('55)； 74) 池田重良：日化, 76, 1122 ('55); 東 北大研, A, 8, 9 ('56)；75) 池田重良: 日化, 76, 1258 ('55); 76) S. Ikeda: Sci. Repts. Research Inst., Tohoku Univ. Ser., A, 9, 16 ('56); 77) S. Ikeda: ibid., A, 8, 134 ('56); 78) S. Ikeda: ibid., $449\left({ }^{\prime} 56\right)$; 79) S. Ikeda: ibid., 457 (,56); 80) S. Ikeda: ibid., 463 ('56)

81）中井敏夫, 石田良平, 日高さか元: 日化, 73, 19 ('52); 東工 
試報, 50, 35 ('55)； 82) 石田良平：日化, 76, 56 ('55)；東工武 報, 51, 323 ('56)； 83) 石田良平: 日化, 76, 60 ('55); 東工武 報, 51, 329 ('56)； 84） 石田良平: 日化, 77, 238 ('56); 東工試 報, 51, $333\left({ }^{\prime} 56\right)$; 85) 石田良平: 日化, 77,241 ('56); 東丁.試 報, 51, $337\left({ }^{\prime} 56\right) ； 86$ ) 石田良平: 日化, 77, 242 ('56); 東工試 報, 51，339('56)； 87）石田良平，藤代芳正：化学の領域， 8, 163, $239\left({ }^{\prime} 54\right)$ ； 88）石田良平, 藤代芳正, 真中隼太, 橋本勇二郎, 金子 弘德：分光研究， 4, 14 ('56)； 89$)$ 石田良平：分光研究， 4, 3 ('56)；90）石館守三, 益子安, 甘露寺泰雄：薬学雑誌， 75, 1492 ('55)

91) D. N. Ivanov, B. Y. Kaplan: Zavodskaya Lab., 22, 569 ('56); Z. anal. Chem., 155, 51; 92) C. G. James, T. M. Sugden: Nature, 171, 428('53); 93) C. G. James, T. M. Sugden: Proc. Roy. Soc. (London) A, 227, 312 ('54); 95) C. G. James, T. M. Sugden: Nature, 175, 333 ('55); 96）鹿島次郎, 牛田口元堂：分化, 4, 420 ('55)； 97） J. A. A. Ketelaar, C. Haas, F. N. Hooge, R. Broekhuijesen: Physica, 21, 695 ('55); C. A., 50, 8323b; 98) H. Kick: Z. anal. Chem., 151, 406 ('56): 99) V. F. Kitaeva, N. N. Sobolev: Optika i Spekroskopiya, 1, 302 ('56); C. A., 50, 3886c; C. A., 51 ,4817c; 100) H. Kropik: Z. Pflanzenernähr. Düng. Bodenk., 70, 138 ('55)

101) A. Lagerqvist, L. Huldt: Naturwiss., 42, 365('55); 102) H. H. Lausen: Scand. J. Clin. Lab. Invest., 7, 320 ('55); Z. anal. Chem., 153, 239; 103) L. Manna, D. H. Strunk, S. L. Adams: Anal. Chem., 28, 1070 ('56); 104) M. Margoshes, B. L. Vallee: ibid., $1066\left({ }^{\prime} 56\right)$; 105) M. Margoshes, B. L. Vallee; ibid. 180 ('56); 106) G. E. Marsh: Appl. Spectroscopy, 10, 8 ('56); C. A., 50, $5953 \mathrm{~b} ; 107)$ 益子安, 甘露寺泰雄：薬学雑誌, 76, 441('56); 108) 益子安, 甘露寺泰雄：ibid., 689 ('56)；109）养子安：ibid., 1272 ('56); 110) W. T. Mathis: J. Assoc. Offic. Agr. Chem., 38, 387 ('55)

111) W. T. Mathis: J. Assoc. Offic. Agr. Chem., 39 419 ('56); 112) R. Mavrodineanu, H. Boiteux: "L'Analyse Spectrale Quantative par la Flamme” ('54), (Masson, Paris); 113) R. Mavrodineanu: Appl. Spectroscopy, 10, 51 ('56); 114) A. Mehlich: J. Assoc. Offic. Agr. Chem., 39, $330\left({ }^{\prime} 56\right)$; 115) V. W. Meloche: Anal. Chem., 28, 1844 ('56); 116) V. W. Meloche, B. L. Beck: ibid., 1890 ('56); 117) V.S. Mel'chenko: Optica i Spektroskopiya, 1, 321 ('56); C. A., 50, 7569b; C. A., 51, 4817b; 118) E. L. Molt, L. H. Tio: Chem. Weekblad, 52, 313('56); C. A., $50,12374 \mathrm{c} ; 119)$ 车田口元堂：分光研究, 10, 52('55)；120）车 田口元堂：分化, 4, 445 ('55)

121) S. O. Nielsen: Rev. Sci. Instr., 26, $516\left({ }^{\prime} 55\right)$; 122) 日本分析化学会, 日本分光学会共編: “炎光分光分析”, ('54)；123) 日本分析化学会編：“基礎分析化学”一ースペクトロメトリー('56); 124) W. Oelshläger: Z. anal. Chem., 149, 190('56); 125）网田富男, 上田忠雄, 上妻常英: 分光研究, 4, 30 ('56); 126) 大橋九万雄,安井永三,鈴木汎: 工化, 57, 16 ('54)：127） 太田直一 上野佐：日化， 76, 1235 ('55)；128) 音在清辉：最新の分析化学, $\left.5,93\left({ }^{\prime} 54\right) ； 129\right)$ 音在清辉, 福島昭三: 分化, 4, 188('55)；130) 音在清耀：日本分析化学会近幾支部編：“機器分析実匼法” 発光分光 分析篇, 76 ('56) (槙, 東京)

131）大津毅: Jap. J. Med. Sci. Biol., 9, 117 ('56)； 132) 大八木義彦：分化, 4, 179('55)；133） F. M. Page:.Discussions Faraday Soc., 19, 87 ('55); 134) Gh. Pavloschii, E. Gruia: Rev. Chim., Bucharest, 7, 657 ('56); Anal. Abst., 4, 2872; 135) S. S. Penner, E. K. Björnerud: J. Chem. Phys., 23, 143('55); 136) M. Pinta, C. Bove: Mikrochim. Acta 1956, 1788; 137) M. Pinta, C. Bove: Compt. rend., 243, 179 ('56): 138) P. Porter, G. Wyld: Anal. Chem., 27, 733 ('55); 139) M. J. Pro, A. P. Mathers: J. Assoc. Offic. Agr. Chem., 39, 225 ('56); 140) M. J. Pro, R. A. Nelson, A. P. Mathers: ibid., 506 ('56)

141) E. Pungor, E. E. Zapp: Acta Chim. Acad. Sci., Hung., 7, 185 ('55); C. A., 50, 4632e; 142) E. Pungor,
E. E. Zapp: Magyar Kem. Foly., 61, 117('55); Acta Chim. Acad. Sci., Hung., 10, 179 ('56); C. A., 50, 671f; C. A., 51, 5625c; 43) E. Pungor, E. E. Zapp: Magyar Kém. Foly., 61, 421 ('55); Z. anal. Chem., 154, 270; 144) E. Pungor, A. J. Hegedüs, I. K. Thege, E. E. Zapp: Mikrochim. Acta, 1956, 1247; 145) A. O. Rathje: Anal. Chem., 27, 1583('55); 146) C. I. Rich: Proc. Soil Sci. Soc. Amer., 16, 51 ('55); 147) C. F. Rothe: Anal. Chem., 27, 1507 ('55); 148) N. Roy: ibid., 28, 34('56); 149) K. Scharrer, K. Mengel: Landwirtsch. Forsch., 9, 204 ('56); Z. anal. Chem., 157, 65; 150) D. Schroeder: Z. Pflanzenernähr. Düng. Bodenk., 73, 86 ('56): Z. anal. Chem., 155, 58

- 151) W. Schuhknecht, H. Schinkel: Z. anal. Chem., 143，321 ('54)；152）妹尾節哉: 高峰汸究所年報, 7, 110 ('55); 153）炼尾節哉：高峰研究所年報， 8, $113\left({ }^{\prime} 56\right)$; 154) W. M. M. Shaw, N. C. Veal: Soil. Sci. Soc. Am. Proc. 20, 328 ('56); C. A., 50, 17272i； 155) 塩谷正邦, 浅野千秋: 分化, 5, 384 ('56); 156) K. E. Shuler, J. Weber: J. Chem. Phys., 22, 491 ('54); 157) H. Siebert, S. Rapoport: Biochem. Z., 326, 413('55); 158) H. Siebert, S. Rapoport: Z. anal. Chem., 150, 81 ('56); 159) H. Smith, T. M. Sugden: Proc. Roy. Soc. (London), A 219, 204 ('53); 160) N. N. Sobolev: Trudy. Fiz. Inst. Akad. Nauk S. S. S. R., F. Z. Inst. im. P. N. Lehedeve, 7, 160 ('56); C. A., 51, 4137g

161) A. K. Solomon, D. C. Caton: Anal. Chem., 27, 1849 ('55); 162) J. Spector: ibid., 1452 ('55); 163) G. W. Standen, C. B. Tennant: ibid., 28, 858 ('56); 164) J. H. Stewart, Jr., R. C. McIlhenny: U. S. Atomic Energy Comm., Y-1140('56); C. A., 51, 4198f; 165) H. Straubel: Mikrochim. Acta, 1955，329；166）菅原健，小山忠四郎，川崎 蝪子: Bull. Chem. Soc. Japan., 29, $\left.679\left({ }^{\prime} 56\right) ; 167\right)$ T. M. Sugden: "5th Symposium on Combustion" 406 ('55), (Reinhold. Pub. New York); 168) T. M. Sugden, R. C. Wheeler: Discussion Faraday Soc., 19, 76('55); 169) T. M. Sugden: Trans. Faraday Soc., 52, 1465('56); 170) T. M. Sugden: ibid., 1481 ('56)

171）鈴木美栄子, 大八木義彦：臨床病理，4，245（'56)；172） P. W. Sykes: Analyst, 81, 283 ('56)； 173）高橋達郎, 吉田 大輔：分化, 3, 207 ('54); 秦野煙草誈報, 3, 1 ('54)；174) S. Tasaka, Y. Yoshitoshi, I. Kitamura, Y. Endo, T. Maeda, M. Nagasaka, H. Fukushima, Y. Masuyama, M. Takahashi: Sogo Igaku, 11, 129 ('54); C. A., 51, 13986c; 175) A. E. Taylor, H. H. Paige: Anal. Chem., 27, 282 ('55); 176）土橋正二, 関戸栄一: 日化, 77, 708('56); 177) I. Unger, L. Unger Glastechn. Ber., 29, 15 ('56); Z. anal. Chem., 153, 136; 178) R. Valencia: Bull. Soc. Chim. Biol., 38, 1071 ('56); Z. anal. Chem., 158, 148; 179) B. L. Vallee, M. Margoshes: Anal. Chem., 28, 175 ('56); 180) B. L. Vallee, A. F. Bartholomay: ibid., 1753 ('56)

181) I. V. Veits, L. V. Gurvich, V. V. Korobov: Izvest. Akad. Nauk S.S.S. R.,Ser.Fiz., 19, 21('55); C. A., 50, 3886a: 182) F. J. Weinberg: Fuel, 35, 359('56); C. A., 50, 12624g; 183) M. Whisman, B. H. Eccleston: Anal. Chem., 27, 1861 ('55); 184) P. C. Wildy: A. E. R. E. Report C/R 2114, ('56); Anal. Abst., 4, 2890: 185) J. P. Williams, P. B. Adams: J. Amer. Ceram. Soc., 39, 351 ('56); Anal. Abst., 4, 2521; 186) E. G. Will, B. Schwarzkopf: J. Amer. Wat. Wks. Ass., 47, 253 ('55); C. A., 49, 7782e: 187) K. Wohl, F. Welty: "5th Symposium on Combustion", 746 ('55), (Reinhold Pub., New York)； 188) 柳正光, 川久保正 一郎: 窝協誌, 63, 6 ('55)；189）柳正光, 川久保正一郎: ibid., 722 ('55); 190) J. Yamamura, T. Niwaguchi: Kagaku to Sôsa, 9, 111 ('56); C. A., 51, 7939h.

191）横須賀繁, 田中正雄, 森川交樹: 分化, 4, 437 ('55); 192) 横須賀繁：分化, 5, 71 ('56)；193) N. Zaidman D. Orechkin: Novosti Neflyanoi Tekh. Neftepererabotha, 1955, No. 5, 25; C. A., 51, 5625d 